\title{
PLASTIC MECHANISMS FOR THIN-WALLED COLD-FORMED STEEL MEMBERS IN ECCENTRIC COMPRESSION
}

\author{
V. UNGUREANU \\ Politehnica University of Timisoara, Romania \\ Romanian Academy - Timisoara Branch, Romania \\ M. KOTELKO, J. GRUDZIECKI \\ Department of Strength of Materials, Lodz University of Technology, Poland
}

It is very well known that cold-formed steel structures are usually made by thinwalled members of class 4 sections and they are characterised by a reduced post-elastic strength and by a reduced ductility. Since these sections are prematurely prone to local or distortional buckling and they do not have a real post-elastic capacity, the failure at ultimate stage of such members, either in compression or bending, always occurs by forming a local plastic mechanism [1]. This fact suggests the possibility to use the local plastic mechanism to characterise the ultimate strength of such members.

The yield line mechanism analysis has been widely used to study steel members and connections that involve local collapse mechanisms. This method can be used to study post-elastic behaviour, load-carrying capacity, ductility, rotation capacity and energy absorption. A detailed history of yield line mechanism theory has been presented by Zhao [2]. An art review of the application of yield line analysis to cold-formed members has been presented by Hiriyur \& Schafer [3] and Ungureanu et al. make an inventory, classify and range geometrical and analytical models for the local-plastic mechanisms aiming to characterize the ultimate capacity of some of the most used cold-formed steel sections in structural applications [4].

Present paper is based on previous studies and on some latest investigations of authors, as well as the literature collected data. It represents an attempt to study the plastic mechanisms for members in eccentric compression.

The approach is a numerical one, in order to identify the plastic mechanisms of members subjected to eccentric compression about minor axis and the evolution of plastic mechanisms, considering several types of lipped channel sections (see Fig. 1).

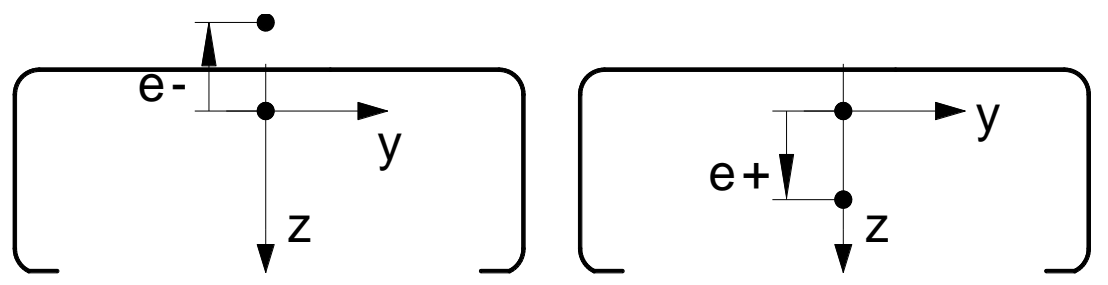

Fig. 1. Example of considered eccentricities

Also, positive and negative eccentricities along the symmetry axis will be investigated, i.e. $-10 \mathrm{~mm},-5 \mathrm{~mm},-2 \mathrm{~mm},-1 \mathrm{~mm}, 0 \mathrm{~mm},+1 \mathrm{~mm},+2 \mathrm{~mm},+5 \mathrm{~mm}$, $+10 \mathrm{~mm}$ and $+20 \mathrm{~mm}$, as shown in Fig. 1 . 
Fig. 2 presents some plastic mechanisms of thin-walled cold-formed steel members subjected to eccentric compression.
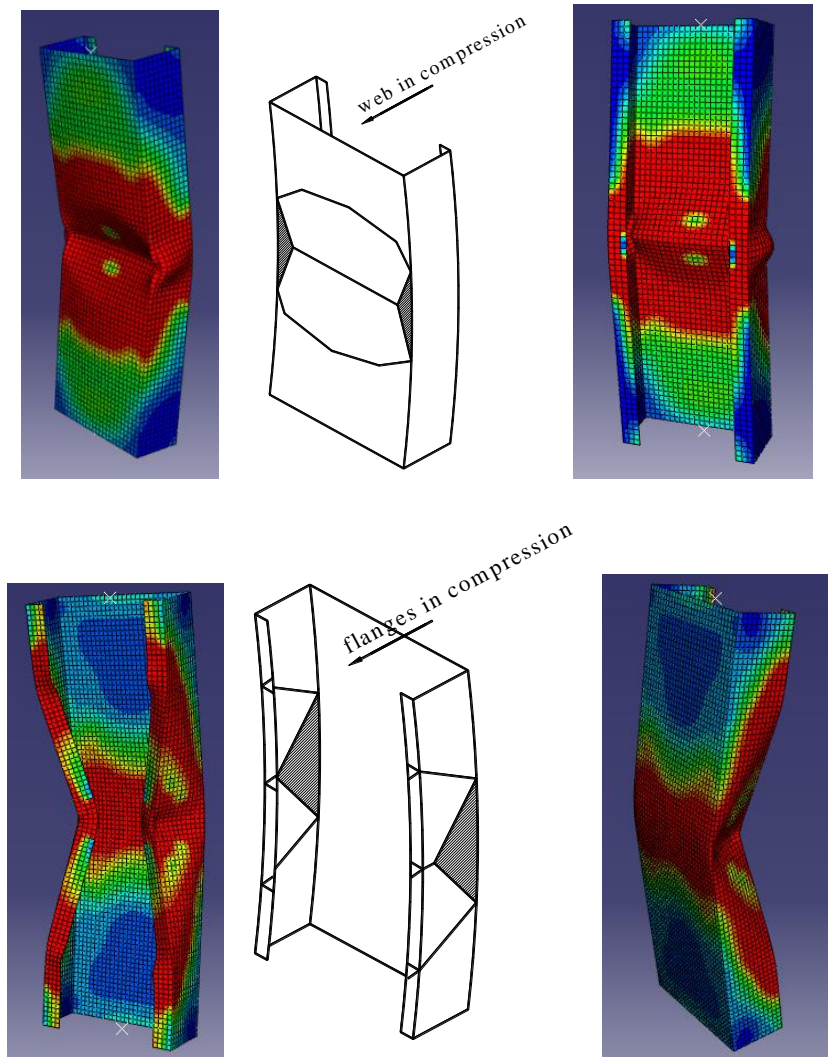

Fig. 2. Plastic mechanisms of members subjected to compression and bending about minor axis

\section{REFERENCES}

[1] Dubina D., Ungureanu V., Plastic strength of thin-walled members, Sixteenth Int. Specialty Conference on Cold-Formed Steel Structures, Orlando, Florida, 2002, pp. 324-332.

[2] Zhao X.-L., Yield line mechanism analysis of steel members and connections, Prog. Struct. Engng. Mater., 5, 2003, pp. 252-262.

[3] Hiriyur, B.K.J., Schafer, B.W., Yield-line analysis of cold-formed steel members, International Journal of Steel Structures, 5, 1, 2004, pp. 43-54.

[4] Ungureanu V., Kotelko M., Mania R.J., Dubina D., Plastic mechanisms database for thinwalled cold-formed steel members in compression and bending, Thin-Walled Structures, 48, 10-11, 2010, pp. 818-826. 